Research Article

\title{
Development and Validation of Stability Indicating UPLC Method for the Estimation of Bilastine in Bulk and Pharmaceutical Dosage Form
}

\author{
Shaista Firdous*1, Dr. S. H. Rizwan² \\ ${ }^{1}$ Research Student, Department of Pharmaceutical Analysis, Deccan School of Pharmacy, Hyderabad, India. \\ ${ }^{2}$ Professor, Department of Pharmaceutical Analysis, Deccan School of Pharmacy, Hyderabad, India. \\ *Corresponding author's E-mail: shaistaf72@gmail.com
}

Received: 03-09-2020; Revised: 22-10-2020; Accepted: 30-10-2020; Published on: 15-11-2020.

\section{ABSTRACT}

A simple, specific, accurate and economic Ultra Performance Liquid Chromatography method was developed for the estimation of Bilastine in bulk and tablet dosage form. The method has shown adequate separation of Bilastine from their degradation products. Separation was achieved on a Phenomenex C8 $(50 \times 2.1 \mathrm{~mm}$ ID, $1.7 \mu \mathrm{m})$ Column at wavelength of $248 \mathrm{~nm}$, using a mobile phase pH 3.5 Sodium Phosphate $10 \mathrm{mM}$ Buffer : Methanol : Acetonitrile $(60: 30: 10 \mathrm{v} / \mathrm{v} / \mathrm{v})$ in an isocratic elution mode at a flow rate of 0.5 $\mathrm{ml} / \mathrm{min}$. The retention time for Bilastine is found to be $1.19 \mathrm{~min}$. The above drug is subjected to acidic, base, peroxide, thermal and photolytic stress environment. The stressed samples are analyzed by the proposed analytical method. Quantitation is achieved with UV detection at $248 \mathrm{~nm}$ based on peak area with linear calibration curve at concentration range $50-150 \mu \mathrm{g} / \mathrm{mL}$. The LOD and LOQ are found to be 0.368 and $1.117 \mu \mathrm{g} / \mathrm{mL}$ respectively. The developed method was established to be rapid, accurate, precise and stability indicating as no interfering peaks at the retention time of Bilastine were observed. The developed method is therefore suitable for purpose in quality-control laboratories for quantitative analysis of drug in pharmaceutical dosage form, as it is simple and rapid with tremendous precision and accuracy.

Keywords: Bilastine, UPLC, Stability Studies, Robustness, Linearity.

QUICK RESPONSE CODE $\rightarrow$

DOI:

10.47583/ijpsrr.2020.v65i01.019

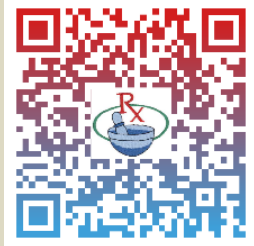

DOI link: http://dx.doi.org/10.47583/ijpsrr.2020.v65i01.019

\section{INTRODUCTION}

ilastine is a new drug in the category of Antihistamines, used for the treatment of allergic reactions like nasal congestion and urticaria. Chemically, it is 2-[4-(2-(4-(1-(2-ethoxyethyl)- $1 \mathrm{H}-$ benzimidazol-2-yl) piperidin-1-yl)ethyl)phenyl]-2methylpropionic acid. It has a molecular formula of $\mathrm{C}_{28} \mathrm{H}_{3} \mathrm{~N}_{3} \mathrm{O}_{3}$ and molecular mass of $463.61 \mathrm{~g} / \mathrm{mol}$. Solubility studies show that it is slightly soluble in water, acetonitrile and soluble in methanol. It is a second-generation histamine $\mathrm{H} 1$ receptor antagonist, acts by binding to the receptor, preventing its activation thereby reduces the development of allergic symptoms. ${ }^{1}$

The present work is aimed to develop a simple, accurate and robust stability indicating method with acceptable retention time in quantitative determination of Bilastine in tablets, to provide a practical approach for stability testing using UPLC to support the in process and stability analysis of Bilastine as very few researches are available in analytical domain.

\section{MATERIALS AND METHODS}

\section{Chemicals and Reagents}

Bilastine API was obtained as gift sample from Symed Labs Limited, Hyderabad, Telangana. HPLC grade Methanol, HPLC grade Acetonitrile were purchased from Thermo Fischer Scientific, Hyderabad, Telangana, India. Analytical grade chemicals and buffers were used. Bilafav, the tablet dosage form of strength $20 \mathrm{mg}$ was obtained from local pharmacy.

\section{Instrumentation}

Spectral measurement was performed using Nicolet Evolution 100 Vision Pro Version 1.06, UV Visible Spectrophotometer. UPLC experiment was carried out on Agilent Technologies, with PDA detector. Data collection and processing was done using Open Lab EZ Chrom software. $\mathrm{pH}$ meter of Global Digital and electronic balance of Mettler Toledo were used.

\section{Identification of Drug}

The identification as well as authentication of procured drug was done by melting point determination (open capillary method) and FT-IR Spectroscopy (Bilastine - KBr pellet was prepared and IR spectrum was recorded).

\section{Selection of Wavelength}

For the wavelength of maximum absorption $\left(\lambda_{\max }\right)$ of the drug, $10 \mu \mathrm{g} / \mathrm{mL}$ standard solution was scanned within the wavelength region of $200-400 \mathrm{~nm}$ against methanol as blank in UV Visible Spectrophotometer. From the 
absorption curve, $248 \mathrm{~nm}$ is selected as working wavelength as maximum absorption is observed at this wavelength.

\section{Chromatographic Conditions}

The chromatographic separation was performed using Phenomenex C8 column (50x2.1mm ID 1.7 $\mu \mathrm{m})$. The mobile phase used for analysis was Sodium Phosphate $10 \mathrm{mM}$ Buffer ( $\mathrm{pH}$ adjusted to 3.5 by ortho-phosphoric acid) : Methanol : Acetonitrile (60:30:10 v/v/v) in isocratic elution mode while maintaining the column temperature at $30^{\circ} \mathrm{C}$. The flow rate was maintained at $0.5 \mathrm{~mL} / \mathrm{min}$, injection volume $-20 \mu \mathrm{L}$ and the run time was $5 \mathrm{~min}$. The retention time of Bilastine was found to be $1.19 \mathrm{~min}$. A typical chromatogram of Bilastine is shown in figure 1.

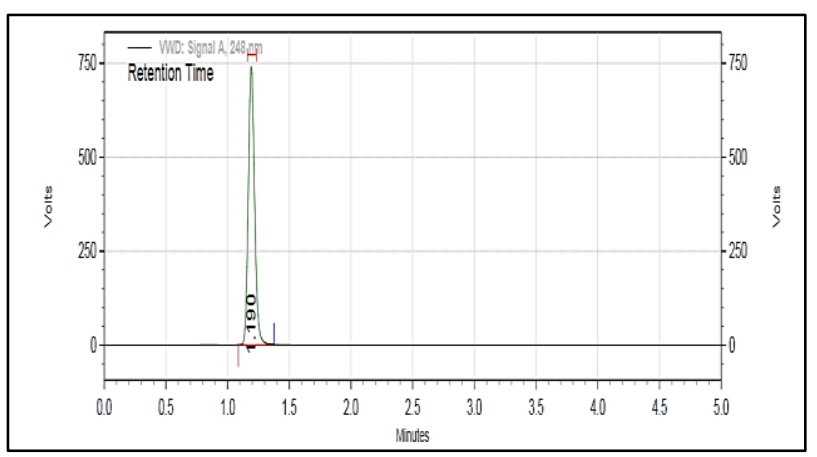

Figure 1: UPLC - Chromatogram of Bilastine

\section{Method Validation}

\section{System Suitability}

For assessing system suitability, injections of standard solutions of $100 \mu \mathrm{g} / \mathrm{mL}$ were given for six times and chromatograms were observed. Parameters like plate number $(\mathrm{N})$, tailing factor $(\mathrm{K})$, retention time and peak area were calculated.

\section{Specificity}

Specificity is the degree to which the method applies to a single analyte; checked in each analysis by examining blank matrix samples for any interfering peaks. Blank and Placebo solutions were prepared, injected and the chromatograms were recorded for both the solutions.

\section{Linearity}

Linearity was demonstrated from five different concentration levels, in the range of $50-150 \mu \mathrm{g} / \mathrm{ml}$. The calibration curve was obtained by plotting peak area $\mathrm{v} / \mathrm{s}$ concentration.

\section{Accuracy}

Accuracy for the developed method was determined by Recovery Studies. To the preanalyzed sample, the reference standards of the drug i.e., $50 \mu \mathrm{g} / \mathrm{mL}, 100 \mu \mathrm{g} / \mathrm{mL}$ and $150 \mu \mathrm{g} / \mathrm{mL}$ were added at the level of $50 \%, 100 \%, 150 \%$ respectively. The recovery studies were carried out three times and the percentage recovery and percentage mean recovery were calculated for the drug.

\section{Precision}

Intraday precision and Inter-day precision were evaluated by carrying out 6 independent sample preparations of $100 \mu \mathrm{g} / \mathrm{ml}$.

\section{Limit of Detection}

LOD of an analytical procedure is the lowest amount of analyte that can be detected but not necessarily quantified. The standard deviation and response of the slope are estimated from calibration curve of the analyte.

$\mathrm{LOD}=\frac{3.3 \sigma}{\mathrm{S}}$

\section{Limit of Quantitation}

LOQ can be defined as the lowest amount of an analyte of a sample which can be quantitatively determined with suitable precision and accuracy. The standard deviation and response of the slope are estimated from calibration curve of the analyte.

$\mathrm{LOQ}=\frac{10 \sigma}{\mathrm{S}}$

\section{Robustness}

The robustness of the assay method was established by introducing small changes in the chromatographic condition which included flow rate $(0.4$ and $0.6 \mathrm{~mL} / \mathrm{min})$, temperature $\left(25^{\circ} \mathrm{C}\right.$ and $\left.35^{\circ} \mathrm{C}\right)$ and composition of organic phase - Buffer : Methanol : Acetonitrile (60: $25: 15 \mathrm{v} / \mathrm{v} / \mathrm{v}$ and $60: 35: 5 \mathrm{v} / \mathrm{v} / \mathrm{v})$.

\section{Assay}

\section{Preparation of Standard Solution}

For the preparation of standard solution, $100 \mathrm{mg}$ of Bilastine was taken in a $100 \mathrm{ml}$ volumetric flask, dissolved in mobile phase and volume was made up to the mark with the same. From this solution $100 \mu \mathrm{g} / \mathrm{ml}$ of solution was prepared by diluting $1 \mathrm{ml}$ to $10 \mathrm{ml}$ with mobile phase.

\section{Preparation of Sample Solution}

\section{Sample name: BILAFAV 20mg}

Weigh 20 tablets and crush with mortar and pestle, then weigh a quantity of powder equivalent to $100 \mathrm{mg}$ of Bilastine and transferred in to $100 \mathrm{ml}$ volumetric flask and dissolved in mobile phase and then make up to the mark with mobile phase and prepare $100 \mu \mathrm{g} / \mathrm{ml}$ of solution by diluting $1 \mathrm{ml}$ to $10 \mathrm{ml}$ with mobile phase.

\section{Forced Degradation Studies}

\section{Preparation of stock solution}

Accurately weigh $10 \mathrm{mg}$ of Bilastine in $10 \mathrm{ml}$ of volumetric flask then add small quantity of diluent and dissolve it. Finally make the volume up to the mark with diluent and filter $1 \mathrm{ml}$ of filtered stock solution was transferred to $10 \mathrm{ml}$ of volumetric flask and made up with diluent. $(100 \mu \mathrm{g} / \mathrm{ml}$ of Bilastine) 


\section{Acidic degradation}

To $1 \mathrm{ml}$ of stock solution of Bilastine, $1 \mathrm{ml}$ of $5 \mathrm{~N} \mathrm{HCl}$ was added and solution was kept for $4 \mathrm{hrs}$ at $60^{\circ} \mathrm{C}$. The resultant solution was neutralized by $1 \mathrm{ml}$ of $5 \mathrm{~N} \mathrm{NaOH}$ and then diluted to obtain $10 \mu \mathrm{g} / \mathrm{ml}$ solution of drug. The solution was cooled, filtered with $0.45 \mu \mathrm{m}$ membrane filter and 10 $\mu \mathrm{l}$ was injected into the system and the chromatograms were recorded to assess the stability of sample.

\section{Alkaline degradation}

To $1 \mathrm{ml}$ of stock solution of Bilastine, $1 \mathrm{ml}$ of $5 \mathrm{~N} \mathrm{NaOH}$ was added and solution was kept for $4 \mathrm{hrs}$ at $60^{\circ} \mathrm{C}$. The resultant solution was neutralized by $1 \mathrm{ml}$ of $5 \mathrm{~N} \mathrm{HCl}$ and then diluted to obtain $10 \mu \mathrm{g} / \mathrm{ml}$ solution of drug. The solution was cooled, filtered with $0.45 \mu \mathrm{m}$ membrane filter and $10 \mu \mathrm{l}$ was injected into the system and the chromatograms were recorded to assess the stability of sample.

\section{Oxidative Degradation}

To $1 \mathrm{ml}$ of stock solution of Bilastine, $1 \mathrm{ml}$ of $30 \%$ hydrogen peroxide was added. The solution was kept on benchtop for $5 \mathrm{hrs}$. The resultant solution was diluted to obtain $10 \mu \mathrm{g} / \mathrm{ml}$ solution of drug and $10 \mu \mathrm{l}$ was injected into the system and the chromatograms were recorded to assess the stability of sample.

\section{Photolytic Degradation}

To study the effect of photolysis, $5 \mathrm{ml}$ of stock solution was exposed to UV light at 1.2 million lux-hours for $4 \mathrm{hrs}$ in photostability chamber. $1 \mathrm{ml}$ of the resultant solution was diluted to obtain $10 \mu \mathrm{g} / \mathrm{ml}$ solution of drug and $10 \mu \mathrm{l}$ was injected into the system and the chromatograms were recorded to assess the stability of sample.

\section{Thermal Degradation}

The drug solution was placed in oven at $105^{\circ} \mathrm{C}$ for $24 \mathrm{hrs}$ to study dry heat degradation. $1 \mathrm{ml}$ of the resultant solution was diluted to obtain $10 \mu \mathrm{g} / \mathrm{ml}$ solution of drug and $10 \mu \mathrm{l}$ was injected into the system and the chromatograms were recorded to assess the stability of sample.

\section{RESULTS AND DISCUSSION}

\section{Identification of API}

Identification and authentication of the procured drug was done by melting point determination and FT-IR Spectroscopy. The IR spectrum of Bilastine API is shown in figure 2.

Melting point of Bilastine was observed in the range of 200 $-201^{\circ} \mathrm{C}$ which is similar to the reported value $\left(200.3^{\circ} \mathrm{C}\right)$.

The sample spectrum matches with the reference spectrum and the practical value of melting point also matches with the theoretical value. This confirms the purity of Bilastine sample.

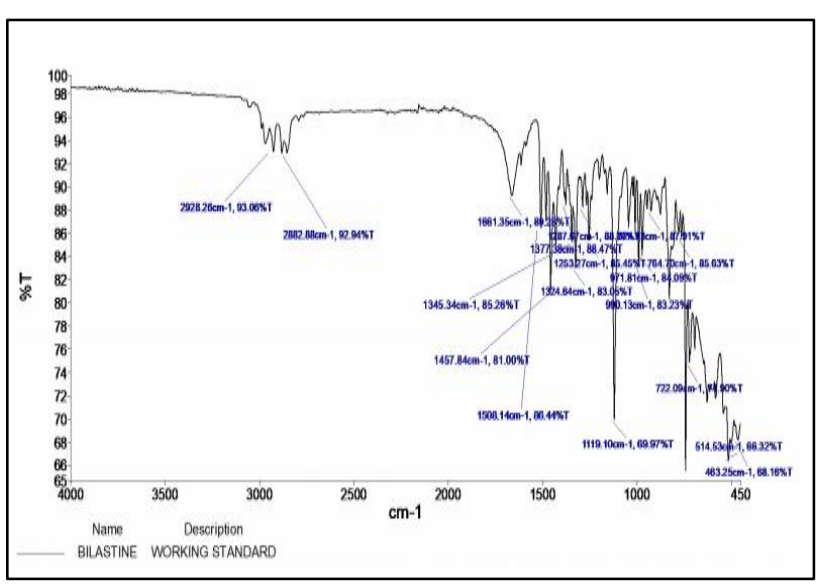

Figure 2: IR Spectrum of Bilastine API

\section{System Suitability}

The \% Relative Standard Deviation for the retention times and peak area of Bilastine were found to be less than $2 \%$. The plate count and tailing factor results were found to be well within the limit. Results of System Suitability are tabulated in table 1.

Table 1: Results of System Suitability, Accuracy, Precision

\begin{tabular}{|c|c|c|c|}
\hline & Injection & $R T$ (min) & Peak area \\
\hline \multirow{2}{*}{$\begin{array}{c}\text { System } \\
\text { Suitability }\end{array}$} & Mean & 1.189 & 415908512 \\
\hline & $\% R S D$ & 0.11 & 0.01 \\
\hline \multirow{4}{*}{ Accuracy } & $\begin{array}{c}\text { Recovery } \\
\text { Level }\end{array}$ & $\% R S D$ & \%Recovery \\
\hline & $50 \%$ & $0.17 \%$ & 100.52 \\
\hline & $100 \%$ & $0.46 \%$ & 99.58 \\
\hline & $150 \%$ & $0.31 \%$ & 99.82 \\
\hline \multirow{4}{*}{ Precision } & Intraday & $\%$ Obtained & $\% R S D$ \\
\hline & assay & \begin{tabular}{|l|l|}
98.56 & 98.25
\end{tabular} & 0.15 \\
\hline & Interday & \% Obtained & $\% R S D$ \\
\hline & assay & 98.90 & 0.04 \\
\hline
\end{tabular}

\section{Specificity}

Chromatograms of blank and placebo solutions showed no peaks at the retention time of Bilastine and it was observed that diluent or excipient peaks do not interfere with the Bilastine peak. The chromatogram of placebo is shown in figure 3 .

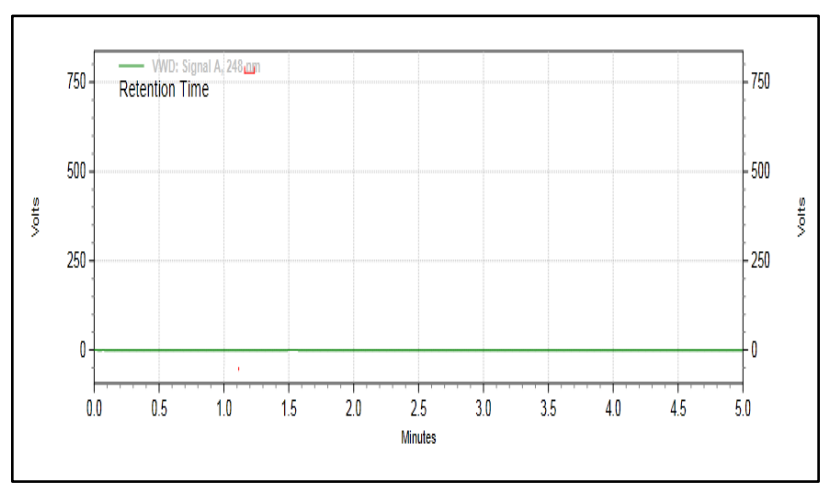

Figure 3: Chromatogram of Placebo 


\section{Linearity and Range}

The calibration plot was linear over the concentration range as shown in figure 4 . Correlation coefficient $R^{2}$ was found to be 0.9992 across the concentration range of 50 $150 \mu \mathrm{g} / \mathrm{mL}$. Results are tabulated in table 2.

Table 2: Results of Linearity

\begin{tabular}{|c|c|c|}
\hline S. No & Concentration $(\mu \mathrm{g} / \mathrm{mL})$ & Area \\
\hline 1 & 50 & 19061043 \\
\hline 2 & 80 & 33056236 \\
\hline 3 & 100 & 44024641 \\
\hline 4 & 120 & 54032671 \\
\hline 5 & 150 & 70024268 \\
\hline
\end{tabular}

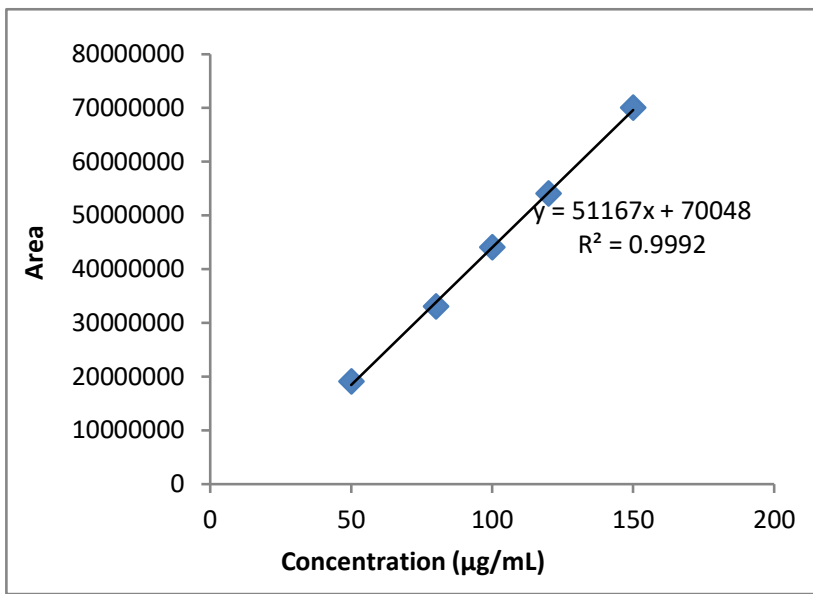

Figure 4: Calibration Curve for Linearity

\section{Accuracy}

Accuracy of the proposed method was assessed by performing Recovery Studies. The percentage mean recovery of Bilastine was found to be $99.97 \%$ and \%RSD was found to be less than 2. Results of Accuracy are shown in table 1.

\section{Precision}

Intraday precision and inter-day precision were evaluated by carrying out six independent sample preparations (100 $\mu \mathrm{g} / \mathrm{mL}$ concentration). \%RSD were found to be less than 2\%. Results of Precision are shown in table 1.

\section{Limit of Detection and Limit of Quantitation}

The LOD and LOQ which produced requisite precision and accuracy were found to be $0.368 \mu \mathrm{g} / \mathrm{mL}$ and $1.117 \mu \mathrm{g} / \mathrm{mL}$ respectively.

$$
\begin{aligned}
& \mathrm{LOD}=\frac{3.3 \times 6112}{51167}=0.368 \mu \mathrm{g} / \mathrm{mL} \\
& \mathrm{LOQ}=\frac{10 \times 6112}{51167}=1.117 \mu \mathrm{g} / \mathrm{mL}
\end{aligned}
$$

\section{Robustness}

Robustness was assessed by making deliberate variations in method parameters of flow rate, temperature and composition of organic phase. The results were in favor of (\% RSD $<2 \%$ ) the developed UPLC method for the analysis of Bilastine. The results are shown in table 3.

\begin{tabular}{|c|c|c|c|c|}
\hline \multicolumn{3}{|c|}{ Chromatographic Changes } & $\begin{array}{c}\text { RT } \\
\text { (min) }\end{array}$ & $\begin{array}{l}\text { Peak } \\
\text { Area }\end{array}$ \\
\hline \multirow{2}{*}{ Flow rate } & $\begin{array}{c}-1 \\
\mathrm{~mL} / \mathrm{min}\end{array}$ & $\begin{array}{c}0.4 \\
\mathrm{~mL} / \mathrm{min}\end{array}$ & 1.473 & 41906763 \\
\hline & $\begin{array}{c}+1 \\
\mathrm{~mL} / \mathrm{min}\end{array}$ & $\begin{array}{c}0.6 \\
\mathrm{~mL} / \mathrm{min}\end{array}$ & 0.973 & 41579667 \\
\hline \multirow{4}{*}{$\begin{array}{c}\text { Column } \\
\text { Temperature }\end{array}$} & & & & $\begin{array}{c}\% R S D= \\
0.55\end{array}$ \\
\hline & $-5^{\circ} \mathrm{C}$ & $25^{\circ} \mathrm{C}$ & 1.143 & 41553243 \\
\hline & $+5^{\circ} \mathrm{C}$ & $35^{\circ} \mathrm{C}$ & 1.137 & 41534121 \\
\hline & & & & $\begin{array}{c}\% R S D= \\
0.03\end{array}$ \\
\hline \multirow{3}{*}{$\begin{array}{c}\text { Organic } \\
\text { Phase } \\
\text { (Methanol : } \\
\text { ACN) }\end{array}$} & $\begin{array}{l}-5 ;+ \\
5(v / v)\end{array}$ & $\begin{array}{c}25: 15 \\
(v / v)\end{array}$ & 0.933 & 41572364 \\
\hline & $\begin{array}{l}+5 ;- \\
5(v / v)\end{array}$ & $\begin{array}{l}35: 5 \\
(v / v)\end{array}$ & 1.503 & 41580278 \\
\hline & & & & $\begin{array}{c}\% R S D= \\
0.39\end{array}$ \\
\hline
\end{tabular}

Table 3: Results of Robustness

\section{Assay}

The tablet formulation under the brand name Bilafav of strength $20 \mathrm{mg}$ was used for assay. The procedure was repeated for 5 injections. The drug content was estimated to be $100.4 \%$

$$
\% \text { Assay }=\frac{A T}{A S} \times \frac{\mathrm{WS}}{D S} \times \frac{\mathrm{DT}}{W T} \times \frac{\mathrm{P}}{100} \times \frac{\mathrm{AV}}{L C} \times 100
$$

\section{Stability Studies}

Drug sample of Bilastine was subjected to stress conditions and it was found that maximum degradation was observed in peroxide hydrolysis and minimum degradation was observed in photolytic degradation. Results of Stability Studies/ Forced Degradation Studies are shown in table 4.

Table 4: Degradation data of Bilastine

\begin{tabular}{|c|c|c|c|}
\hline Degradation Condition & Peak Area & \% Recovery & \% Degradation \\
\hline Unstressed Sample & 42609769 & 100 & - \\
\hline Acid Hydrolysis & 41118427 & 96.5 & 3.5 \\
\hline Alkaline Hydrolysis & 41800183 & 98.1 & 1.9 \\
\hline Peroxide Hydrolysis & 40266231 & 94.5 & 5.5 \\
\hline Thermal & 42268890 & 99.2 & 0.8 \\
\hline Photolytic & 42354111 & 99.4 & 0.6 \\
\hline
\end{tabular}




\section{CONCLUSION}

A simple, fast, accurate and precise stability indicating UPLC analytical method has been developed and validated for the quantitative analysis of Bilastine in bulk drugs and tablet dosage forms. The analytical method was found to be stable and sensitive, without any degradation products. Forced degradation studies were carried under various stress conditions and it was observed that under peroxide hydrolysis condition, the degree of degradation of Bilastine was higher i.e., 5.5\% and under photolytic degradation condition, the degree of degradation of Bilastine was found to be as low as $0.6 \%$. From the above experimental results and parameters it was concluded that, the newly developed method for estimation of Bilastine was found to be simple, fast, precise, accurate sensitive and reproducible and hence it can be effectively proposed that the developed method can be applied for the analysis of routine quality control samples and samples obtained from stability studies.

Acknowledgement: The authors are thankful to Symed Labs Ltd., Hyderabad, India for providing the gift sample of Bilastine for carrying out the research work.

\section{REFERENCES}

1. Bilastine - DrugBank. Available from: https://www.drugbank.ca/drugs/DB11591

2. Silva, Andressa \& Brabo, Gabriela \& Marques, Isadora \& Bajerski, Lisiane \& Malesuik, Marcelo \& Paim, Clésio, UV Spectrophotometric method for quantitative determination of Bilastine using experimental design for robustness, Drug Analytical Research, 1, 2017, 38-43.
3. Chowdary V, Method development and validation of new RPHPLC method for the estimation of Bilastine in pharmaceutical dosage form, World Journal of Pharmacy and Pharmaceutical Sciences, 2017, 2297-2315.

4. Terzić, Jelena \& Popović, Igor \& Stajić, Ana \& Tumpa, Anjai \& Jancic Stojanovic, Biljana, Application of Analytical Quality by Design concept for bilastine and its degradation impurities determination by hydrophilic interaction liquid chromatographic method, Journal of Pharmaceutical and Biomedical Analysis, 125, 2016, 385-393.

5. Prathyusha $P$, Sundararajan $R$, Bhanu $P$, Mukthinuthalapati MA, A new stability indicating RP-HPLC method for determination of Bilastine in bulk and pharmaceutical formulation, Research J. Pharm. And Tech, 13(6), 2020, 28492853.

6. Motta PR, Porto DS, Martini PRR, Bajerski L, Azeredo JB, Paula FR, Paim CS, Bilastine: Quantitative Determination by LC with Fluorescence Detection and Structural Elucidation of the Degradation Products Using HRMS, Journal of AOAC International, 2020, qsaa059.

7. Prathyusha $P$, Sundararajan R, UV spectrophotometric method for determination of Bilastine in bulk and pharmaceutical formulation, Research J. Pharm. And Tech, 13(2), 2020, 933-938.

8. Payali PJ, Gaware VM, Dhamak KB, Development and Validation of RP-HPLC Method for the Estimation of Bilastine from bulk and Formulation, Asian Journal of Pharmaceutical Analysis, 10(2), 2020, 109-111.

9. Ouarezki, Radia \& Guermouche, Saliha \& Guermouche, Moulay-Hassane, Degradation kinetics of Bilastine determined by RP-HPLC method and identification of its degradation product in oxidative condition, Chemical Papers, 74, 2019, 1-10.

Source of Support: None declared.

Conflict of Interest: None declared.

For any question relates to this article, please reach us at: editor@globalresearchonline.net New manuscripts for publication can be submitted at: submit@globalresearchonline.net and submit_ijpsrr@rediffmail.com 